\title{
Learning to abide by the Rules of Nature in the Perspective of COVID-19
}

\section{Keywords}

Cosmos, Environment

Stewardship of Man

Balance in the Nature

COVID-19

Islamic Financial Institutions

\begin{abstract}
Each and every element in the universe is playing a given role in maintenance and preservation of the systems it comprises. The universe and whatever it comprises offers strong signs for people provided they have sense to understand (Qur'ān 2:164). All human beings, their future generations and other creatures on the planet, have an equal right to benefit from the natural resources. Going against the laws of the nature means violating the trust, while abusing the knowledge and power given by Almighty has brought hardships to humanity itself and destruction to life and wealth. Nature requires that all must honor the rights of others by avoiding the immoral and prohibited acts or contracts to exploits the fellow human beings at individual, communal or national levels. The man transgressed and damaged the balance of the nature with its evil deeds and rebellion to the nature's laws. The Qur'ān teaches that human need cannot justify transgressing the equally legitimate needs of other species.

The Corona pandemic has caused economic chaos and uncertainty in the national as also global economies. All countries, developed and underdeveloped, alike are facing an unprecedented economic crisis as they attempt to contain the impact of the pandemic. This editorial relates the current and the earlier pandemics to the transgression of human beings against the nature. Man needs to be pro-humans, pro-nature, pro-environment, pro-market with discipline, and pro-planet, that is the abode for it and for its future generations. The institutions, organizations and the firms that are flying an Islamic flag are under moral obligation to develop and implement the nature friendly principles and standards for their businesses. Specifically, Islamic financial Institutions need to be on the front lines for change in paradigms, policies and their implementation in their business.
\end{abstract}

KAUJIE Classification: H46, H54, L42, N0, T2 JEL Classification: P18, P28, Q51, Q54 


\section{INTRODUCTION}

Covid-19 is raging around the world. The Corona pandemic has caused economic chaos and uncertainty in the national as also global economies. In addition to its implications on employment, business, banking, finance and the wider economy, concerns are also being shown on people's physical and mental wellbeing. Health concerns and feelings of isolation increase the stress at work. The WHO estimates that mental health issues in the workplace are responsible for a $\$ 1000 \mathrm{bn}$ loss in global productivity every year. Losses to the national and global economies are beyond any exact amount or measure. Upcoming problems may relate to growing debt level, bank risk exposure, and sovereign exposures, and emerging distortions in markets both at national and global levels.

Substantial policy measures have been taken in many countries to reduce the severity of losses. But the measures taken lack effective risk sharing across firms and the countries. It is exactly according to the capitalistic mindset, which should have been changed to reduce the losses jointly and to plan for future policy measures for abiding by the norms of the nature at corporate, national and global levels. Turkish president Recep Tayyip Erdogan very rightly suggested in the 2020 Global Vaccination Summit held in London;

"The pandemic should not be allowed to lead to further divisions in the world. Its vaccination should be a common property of all humankind and produced at an adequate quantity for all. "COVID-19 has reminded us once again that we are actually one big family sharing a common fate and future"1.

The Universe is designed to function as a whole. Each of its complementary parts has to play an assigned role, and the man is a part of it functioning as a trusty (Qur'ān, 45:13). Allah Almighty has created the world and the universe perfect in proportion, measure and balance as a life-supporting system (Qur'ān, 67:3, 4). "Indeed the earth and what it contains is a means of subsistence for all creatures, not only for humans" (Qur'ān, 15:19, 20). All elements in the universe are interconnected having a value to each other, over and above their value to human beings.

The current pandemic has made the human beings helpless before a tiny creature that can neither be called alive nor dead. Equipped with atomic bombs and missiles, humanity is overwhelmed by an insect that is not easy to see through a microscope. Each corona virus virion is around 120 nanometers in diameter, meaning about 750 of them could fit across the width of a human hair. As per Qur'ān, this is admonition from the nature requiring the human beings to mend themselves for the salvage from the calamities and the recurring ecological, economic, financial and social crises.

All natural pandemics and calamities are result of man disobedience to Almighty and the rebellion against the laws of the nature:

"Whatever strikes you of disaster-it is for what your hands have earned; But much of it He forgives. And you will not cause failure [to Allah] upon the earth; you have no protector nor helper against Allah" (Qur'ān, 42:30, 31).

${ }^{1}$ https://www.aa.com.tr/en/latest-on-coronavirus-outbreak/virus-shouldnt-deepen-injustices-across-worlderdogan/1865382 
Qur'ān says about punishment to the people of Aad:

"We sent upon them a fierce wind on inauspicious days so that We might make them taste a degrading chastisement in the life of this world. And surely the chastisement of the Hereafter is even more degrading. There will be none to help them there" (41:16).

The real impact of Covid-19 might be known after the third quarter of 2020. In respect of consumers, there have been massive mortgage loan / housing finance defaults, credit card defaults and auto loan defaults are expected in all national economies. Besides, a large number of bankruptcies have been filed leading to closure of many big business entities, unemployment and huge losses to almost all economies.

This editorial is to take stock of the possible factors behind the ravage of the nature directing human beings stranded in the impasse and suggest to all that abiding by the norms of the nature is the only way out of the impasses in which the human beings remain generally stuck up.

\section{Nature's Warnings and Reprisal}

Nature keeps on giving warning time to time, requiring man to abide by its rules and to pay gratitude to Almighty, the Creator of the Universe, otherwise they themselves would meet with an evil end. As in the past history, human beings have witnessed some very horrible calamities in last few decades in the form diseases, pandemics, earthquakes, and tsunamis, almost every year since 2004 earthquake and tsunami. The most serious and the recent pandemic is COVID-19. Man's helplessness before nature in such catastrophes is obvious, but the human being generally ignored or forgot any such warnings, and in some cases even started thinking of himself as God. Fourteen hurricanes of Category 5, considered earlier the most dangerous category, occurred in the last about 20 years. The total energy released during the entire period of a Category 5 hurricane is 200 times the total electricity generation worldwide. The 2004 earthquake of 9.1-9.3 mm scale that triggered a series of tsunamis, shook the planet and killed at least 230,000 people in 14 countries. The energy released in such quakes was estimated equivalent to the energy of 1,500 Hiroshima-sized atomic bombs. But the intensity of the hurricane in 2017 was much higher than a Category 5 hurricane, which led to the debate over whether to increase the hurricane categories. Amidst the proclamation of global warming around the world, many countries in the world faced a cold storm in 2019, where the temperature dropped in matter of days below the North and South Poles temperature; as below as minus 55 degrees Celsius in some parts of USA. It also affected thousands of flights and livelihoods. But the human beings are not ready to learn a firm lesson, i.e. bowing to Allah alone and His Mighty Authority over each and every particle of the whole Universe. The beginning verse of the first chapter of Qur'ān (al-Fatiah) requires the human beings to proclaim that "all praise belongs to Allah, the Lord of the Universe" (01:01). It may imply that as human's rebellion continued, the shocks caused by the nature increased in severity. As the humans increasingly consider themselves freer from Divine authority and the limits imposed by the nature, the catastrophes are more and more severe and deadlier. 
Law of nature that comprise "TRUTH-Al Haqq" is different from the Sharí'ah, or the law of courts in the world. The maqāsid al-Sharī'ah law may have blessing-Almighty may forgive anyone; but the nature take its own course-takes revenge. If a person or a nations contradicts nature's rubric creating imbalances, corrupts the systems for exploitation of the weak and the indigent, goes against the principle of moderation in any walk of life, behaves unnaturally in terms of work and leisure habits, diet, extramarital or unnatural sensual relations / flirtation, or even in respect of social norms as required by the nature, that would be punished by the nature to take revenge.

Man, on the other hand wishes to control the nature-individually or as nations, trying to getting larger and larger share without taking into consideration the impact on the natural balance, and this leads to devastation at colossal levels. In this context, (Qur'ān, 23:71) warned, "if the Truth had followed their wishes or inclinations, the heavens and the earth and whoever is in them would have been ruined". The human beings, as a result of adopting atheism and ignoring accountability to Allah in the Hereafter, have earned, as a whole, wickedness, tyranny and oppression. Qur'ān explains the impact of not accepting the authority of the nature, not applying or abrogating the natural law by the human beings:

"Corruption / disorder has spread on the land and at sea, as an outcome of what the human beings have done themselves; this in order that He may cause them to have a taste of some of their deeds; perhaps they would turn back (from evil)" (Qur'ān, 30:41).

We need to be pro-humans, pro-nature, pro-environment, pro-market with discipline, and pro-planet, that is the abode for us and for our future generations. Nature requires that all must honor the rights of others by abiding by the immoral and prohibited acts or contracts to exploits the fellow human beings at individual, communal or national levels. Accordingly, the interest, usury, short selling, deception, adulteration, lack of proper disclosures with objective to deceive others, or any other act / activity / trick to benefit unjustly result in exploitation of others and therefor, annoy or irritate the nature. The nature, in turn, takes reformatory actions to restore the balance, the process in which sometimes the whole nations are replaced with the new one (Qur'ān, 2:251).

\section{Man, Nature, Universe and Islam}

Nature is the cosmos or the phenomenal world or 'Universe'. The explanation of the term 'nature' can be had from Qur'ān, which used at many places the phrases "heaven and earth and everything between them" to describe the whole nature, universe, a complex but orderly system created by Allah (SWT). At places, Qur'ān mentions the Universe with more detail about its elements including the sun, moon, mountains, sea, water, winds, iron, clouds, rain, and also some animals and plants. Small cosmos which means human being, while the big cosmos comprises every phenomenal things besides human. Everything besides Allah is created by Allah, then the 'World' ('âlam) is also meant all Allah's creation (makhlük), so $\mathrm{He}$ is the creator of 'ālameen (Qur'ān, 1: 1).

The concept of 'nature' is also linked to the term āyah (for singular, or $\bar{a} y \bar{a} t$ for plural). Qur'ān has used this term frequently to describe the nature. Basically, $\bar{a} y a h$ means symbol or sign-a thing or an event that represents or is submitted to something else. Besides for nature, 
the term āyah is also used by the Qur'ān itself as the words of Allah Almighty contained in it (Zarman, 2016). It shows that there is something common between Qur'ān and the nature. Qur'ān frequently indicates that the heaven and earth and everything between them are truly the signs of the Almighty. Anyone who is able to arrive at this conclusion would be abiding by the commandments of Allah for all parts of life.

The nature is thus the medium for human to recognize Allah and pay gratitude to Him in all situations. Qur'ann (38:27) indicates that the creation of the cosmos is not purposeless as believed by some, nowadays or in the past- "And we do not create the heaven and earth and what is between them in vain". While Qur' ann is the revealed Book, the cosmos is the created book from Almighty; both are for the guidance of the mankind (Zarman, 2016).

As such, Islamic approach to the environment is holistic. Man created from the essence of nature is inextricably bound to it. "Everything in creation is linked to everything else; whatever affects one thing ultimately affects everything" (Rizk, 2014). Qur'ān requires believers to make the best use of intellect for maintaining the balance and proportion the Almighty has built into His creation. The earth's resources land, water, air, minerals, forests are gift for humanity with certain ethical restraints imposed by nature on them. We may use the resources available in the nature to meet our needs by ensuring that it does not upset ecological balance and that the ability of future generations to meet their needs is not compromise.

So, Qur'ān and the nature both require the human beings to take care of this world as also the world hereafter-the two worlds that have strong relation. A corollary of this derivation is that the man while doing efforts for enhancing earnings and position in the society, must keep in view the impact on fellow beings, other creatures, and the environment as a whole. The verse of (Qur'ān, 30:41), "Corruption has appeared on land and sea as an outcome of what men's hands have wrought: and so He will let them taste the evil of some of their doings, so that they might return to the right path" implies that destruction of the natural environment follows from immoral and unethical use of natural resources. Therefore, the climate change has been argued as the nature's attempt to regain balance following the human assault against it (Al-Qaradawi, 2000; Rizk, 2014).

\section{Man's Supremacy in the Universe}

Creation of the Universe and the man is as per intention of Allah almighty; neither a consequence of any incident, nor it's created in vein (Qur'ān, 3:191). Man's behavior and all human activities have to be aligned with the requirements of the Universe as ordained by Allah Almighty (Zaman, 1986). "Man has been given the finest body among all living beings, and blessed with the noblest faculties of thought, knowledge and intellect; but then it reverted to the lowest of the low; except for those who have faith (in Allah) and do righteous deeds" (Qur'ān, 95: 4, 5). As explained by Syed Abul A'la Maudoodi (in Tafheem), "when man uses the powers of his body and mind in evil ways, Almighty grants him the power to do only evil, which causes him to reach the lowest ebb of degradation". Human history reveals that any individuals or nations blinded by hostility to other individuals or nations, they surpassed all savage beasts in barbarity. 
In spite of all degradation and transgression, Almighty relaxes and forgives many of the evil deeds giving admonished to return to Him. But, it should not mean that they would not be accountable for their evil deeds that tend to create imbalanced in the Universe and the socio-economic system and that they would escape Allah's punishment. Qur'ān (40:4) indicates to the Prophet (PBUH), "So let not their strutting about in the land delude you as those who adopt the attitude of disputation can never escape the punishment-they shall inevitably meet their doom". This, in fact, is a respite which they have been granted by Allah.

\section{The Nature and the Principle of Balance}

Nature has been created on the principle of balance. As steward, human beings need to ensure that their actions do not disrupt the balance. Qur'ān has reminded humanity to observe the balance for its own benefit, and not to transgress it:

"The All-Merciful has taught the Qur'ān. He created man and has taught him articulate speech. The sun and the moon follow a reckoning, and the stars and trees bow themselves; and He raised up the heaven and has set a balance; and that you may not transgress in the balance, but weigh things equitably and skimp not in the balance. And earth - He set it down for all beings; and therein are fruit and palm-trees with their dates in sheaths, and a variety of corn with both husk and grain. Which of your Lord's bounties will you deny?" (55:1-12).

As such, Qur'ān advises for moderation in all aspects of life, and all human actions should be guided with the spirit of moderation. It also includes the use of natural resources for production and consumption. These principles of moderation, balance and conservation are the core of sustainable development strategies. Otherwise, there would be no limits to waste, extravagance or greed at both individual as well as corporate levels. Hence, the use of nature's resources have to be in accordance with human beings material and spiritual needs, the needs of other creatures, now and in the future, so that we do not jeopardise the planet itself.

\section{The Economics and Finance World view against the Rules of Nature}

While discussing the impact of Corona on human life and economies, we need to ponder about the objective and essence of life in the Universe and the built-in consciousness among the human beings to differentiate between good and evil, and need for fairness and justice. The objective has to be sharing the bounties of the nature in cooperative and risk-reward sharing arrangements, and care for the future generations. If human beings are really different from the animals and beasts, they must understand that the life is not without any purpose, and believe in accountability on the Day of Judgment. They also need to ponder the essence of goodness, kindness and charity and how the same are different from evil, arrogance and greed making the human life miserable as a whole.

The current economic, business and finance disciplines, allow on the other hand, people to make money from money in unproductive activities leading to exploiting the majority by the 
few who are already rich, without contributing anything to goods and services to be used by the mankind. As per the natural law, on the other hand, money has to serve as a medium of exchange, and not a commodity for trading as in normal businesses.

The financialization process, where profit is increasingly based on increasing leverage rather than real assets, and where returns come more from a lottery-like business in financial derivatives-prevents the development and perfection of human personality (Epstein, 2005). Economic activity as per natural law has to be governed by the code of 'halāl-harām'. If needed, there have to be restrictions in the wider interests of society in case any malicious elements create hurdle in smooth functioning of the systems for shared growth and development. The organizations, corporations, entities and individuals are duty bound to protect the cosmos from harm through their policies and processes. So, an immediate need is the reorientation of finance as a solid link between real economy and the money.

\section{COVID must lead to Solidarity among all Nations}

The essence of feeling grateful to the nature is that human beings accept sovereignty of the Creator of the universe, abide by its rules, behave properly with fellow beings and other creatures of almighty and do not create hurdles in smooth functioning of the systems operating as part of the universe. Such kind of gratitude to the nature that reflects goodwill gesture to fellow beings and different systems operating in the universe is useful for all, the present and the coming generations. As such, there is no room for exploitation of an individual by an individual, or a nation by any other nation. But, practically there is exploitation all around the world, not only of human beings at national and global levels, but also of the nature and the natural resources, thus spoiling the balance required for smooth functioning of the universe. While millions of fellow beings are dying of hunger, billions of dollars are being spent on preparation of deadly warfare. The continuing pandemic teaches the lesson that the move for controlling other nations, cutthroat competition in the corporate world and deceptive means of marketing must now come to an end for mutual survival, shared growth and development at communities as also global level.

\section{The Case for adopting Islamic Finance Principles}

The ' $a l-b a y$ '/risk sharing law of Islamic finance via 2:275 of Qur'ān along the permanent operational ethics of no rib̄/interest, gharar, gambling, and 'short selling' ${ }^{2}$, can be helpful in meeting the challenges facing national and global economies. Value Based Intermediation (VBI) that emerged in global finance in the wake of GFC, 2008 (WB-IDB, 2016; p .6), ensuing to cater an environment where Social and Governance (ESG) aspects, the Sustainable

\footnotetext{
${ }^{2}$ It is pertinent to observe in this context that the given essential operational ethics/unethical exchange transactions, as indicated above, are prohibited in all Divine religions. Buckley (2000) in her comprehensive treatise on teachings relating to usury in Judaism, Christianity and Islam discussed in detail the prohibition in all three religions and the evolutionary process through which rib $\bar{a}$ was rationalized in Judaism and Christianity. She also discussed Islamic banking and concluded that the three religions had a lot of common ground. He observed that the present effort of the Muslims to institutionalize prohibition of interest gave hope to the humanity. "The non-Muslims can learn a lot from the serious effort being made by the Muslims in this age", she added (Cf, Khan, 2012).
} 
Development Goals (SDGs) are ought to be better served . Even the conventional financial institutions and policy movements have lately started to seriously look towards enhanced adoption and implementation of risk sharing finance for serving the real economy in a valuebased manner, akin to the Divine principles of Islamic finance.

Boot et al. (2020) in the wake of Corona pandemic, there has to be any new schemes that could bring funding to firms without increasing their leverage and default risk. "The implied risk sharing equity-like payment structure has positive risk-sharing features for firms, without impinging on ownership structures". For European economies, they have suggested a "pan-European risk-and reward-sharing mechanism for firms, mostly SMEs and privately owned firms generally relying on bank loans, with no access to capital markets". The same is the case of economies like that of Pakistan. Rising corporate debt levels have a negative impact on firms' default risk.

The incremental rise in corporate leverage due to the coronavirus crisis can be reduced by relying more on risk sharing instruments, i.e. the contracts that imply loss absorption in case of poor future firm performance, and reward participation otherwise. Boot et al. (2020) have suggested establishment of a European Pandemic Equity Fund (EPEF). As per suggested features of the Fund, all citizens would participate in the common risks and potential rewards for a broad-based participation. The initial payments to firms from the EPEF would carry no direct repayment obligation, and firm leverage and default risk would not rise as a result of the financing operation. The risk of a future loss of the initial payment would be assumed by the investor, the EPEF; and the future profits would be shared by the EPEF with repayments to the fund being conditional on positive firm performance. The scheme is akin to Islamic capital market instruments based on partnership. The scheme could also work for larger firms, which, of course, have easier access to capital markets.

$S u k \bar{u} k$ that involve a risk sharing mechanism through a securitization mechanism also offer some advantages that are able to cope with the different challenges faced by infrastructure financing. Subject to some Shari' ${ }^{-}$ah restrictions based on the nature of the underlying contract of any $s u k \bar{u} k$, the holders can trade the $s u k \bar{u} k$ to redeem their investment before the maturity date. $S u k \bar{u} k$ also provide a steady and predictable cash flow to the $s u k \bar{u} k$ holders over a long period of time. They could also help in developing an efficient secondary market (Badrudheen \& Azeez, 2019). But, all such suggested tools will be effective only when the essential conditions of the underlying contracts, as per Islamic law, are implemented properly.

Islamic economics, business, banking and finance, if to be really related to the law of the nature, must implement the following principles:

1) If production and business activities are to be carried out through loans and debts, then each and every transaction must be associated by any fresh real business and production activity relating risk and rewards to the ownership;

2) There has to be an equity-based access to capital at least by the SMEs, commodity based micro businesses and smaller, unlisted firms. Special funds may be created for the purpose to be created by the State authorities / departments and the public at large through the routes of direct financial intermediation. 
As required by Islamic cooperative framework, the State, the regulatory authorities and different groups / associations in any society need to create a common perception of shared growth and development, responsibility, prosperity and solidarity; "Make men [and women] work together, show them that beyond their differences and geographical boundaries there lies a common interest." Suggested Jean Monnet, one of the founding fathers of the European Union (Cf. Boot et al., 2020). This philosophy is quite according to the shared development approach suggested by the holy Prophet (PBUH) (Ayub, 2018). So far, no experience has been made of a central bank in an Islamic macro-economic framework. The experts have suggested that a rib $\bar{a}$ free monetary authority could auction money supply on the basis of profit sharing with the competing commercial banks. The sovereign profit share may replace the discount rate for regulating money supply (Uthman, 2001). Further, the state can mobilize funds by commercializing its activities, obtaining infrastructure-related assets on ijārah, procuring goods on the basis of credit, or forward sale of eligible goods on mark-up basis. It would require developing suitable institutional arrangements for proper application of the suggested means (Khan, 2000).

\section{CONCLUSION}

Human beings are responsible and accountable for their conduct towards fellow beings, other creatures, as also the environment. Going against the laws of the nature means violating the trust, while abusing the knowledge and power given by Almighty has brought hardships to humanity itself and destruction to life and wealth. Qur'ān warns time and again that those who abused the power given to them by Allah, they were destroyed by an environmental catastrophe. The reckless productions and distribution of resources by the man today even at the cost of our own abode, the business, financial and anti-social behavior of the nations, organizations, and even the individuals pushing majority of the human beings in abstract poverty and helplessness has invited the wrath of the nature. Hence, the vulnerability of human beings is becoming increasingly evident.

Islamic finance is based on the principle of sharing risk and reward justly. Any returns on one's investments without taking business risk and without value addition are termed as usurious. Similarly, risk shifted to others / insurance companies against the premiums making insurance a commutative contract is prohibited, while mutual risk sharing by takâful policy holders is appreciated in Islamic law. As such, the whole process of money and credit creation, financing based on fractional reserves system, or dealing in derivatives, have to be reviewed to ensure that each and every financial transaction is based on the current or potential capacity of the entity requiring funds or the economy. Whatever money is created over and above that limit, as an unavoidable necessity, that must be social money belong to the whole community. The concept of time value might be applicable only on asset-based exchange transactions such as sales and ijārah where the exchange involves commodity and market risk and reward based on ownership, and the use of asset is relevant to its period.

The risk taking and value addition are carried out by way of trading, leasing, or supply of finance on risk / reward sharing basis. This way, Islamic finance would promote social and sustainable economic development by creating real assets, not just by generating transactions 
that are merely financial. $S \subseteq k \bar{u} k$ are the potential and important new sources of financing to fund long-term projects by mobilizing funds from the private sector. The developing countries may use existing assets, or may build new ones to mobilize resources through $s u k \bar{u} k$ issuance.

It is good to note that UN Environment Program Finance Initiative (UNEPFI) recently established the Principles for Responsible Banking ${ }^{3}$., with many banks from around the world committing to be aligning their business strategies with society's goals. But, the more pressing requirement is that the world now adopts the basic principles of finance not to allow any risk-free and speculation based finance. While the conventional banking and finance authorities around the world are required to redesign the policies, tools and the processes, as a choice, for better future of the mankind, Islamic financial institutions (IFIs) must avoid all such financing that is not associated with real production, business and economic activities, as a requirement for Sharī'ah compliance.

There are some developments in social and environmental responsibility coming arguably only from increased societal and stakeholder pressures (Rizk, 2014). Perhaps it is crucial now for the organizations and entities flying an Islamic flag to develop and implement the nature friendly principles and standards for their businesses. The IFIs need to be on the front lines for change in paradigms and policies, and their implementation.

\section{REFERENCES}

Al-Qaradawi, Y. (2000). Safeguarding the environment in Islamic maqāṣid al-Sharī'ah . UAE: Dar Al Khaleej.

Ayub, M. (2018). Institutionalising 'Waqf' for realising the shared development objective by Islamic banks and financial institutions. Journal of Islamic Business and Management, 8(2), 330-343. doi: https://doi.org/10.26501/jibm/2018.0802-001

Badrudheen, C. P., \& Azeez, A. N. P. (2019). An overview on how șukūk is a convenient tool for infrastructure development in India. Paper presented at the Conference on An Overview on How Sukūk is a Convenient Tool, Aligarh Muslim University, Aligarh, India.

Boot, A. W., Carletti, E., Kotz, H. H., Krahnen, J. P., Pelizzon, L., \& Subrahmanyam, M. G. (2020). Corona and financial stability 3.0: Try equity-risk sharing for companies, large and small (Working Paper No: 81). Leibniz Institute for Financial Research SAFE, Frankfurt, Germany.

Buckley, S. L. (2000). Teachings on usury in Judaism, Christianity and Islam (pp. 386). New York, NY: The Edwin Mellon Press.

Epstein, G. A. (2005). Financialization and the world economy. Cheltenham, UK: Edward Elgar Publishing.

Khan, M. A. (2012). Islamic economics: Annotated sources in English and Urdu (Vol. 5). Leicester, UK: The Islamic Foundation.

${ }^{3}$ https://www.unepfi.org/banking/bankingprinciples/ 
Khan, M. F. (2000). Mobilization of funds on Islamic principles (pp. pp. 388-391). In A. Siddiqi (Ed.), Anthology of Islamic banking. London, UK: Islamic Institute of Banking and Insurance.

Rizk, R. R. (2014). Islamic environmental ethics. Journal of Islamic Accounting and Business Research, 5(2), 194-204. doi: https://doi.org/10.1108/JIABR-09-2012-0060

Uthman, U. A. (2001). Money, interest and an alternative macroeconomic system. International Journal of Economics, Management and Accounting, 9(1), 101-114.

World Bank and Islamic Development Bank Group (2016). Global report on Islamic finance: Islamic finance: A Catalyst for shared prosperity. Islamic Development Group, Washington, DC, US.

Zarman, W. (2016). The concept of nature in Islamic science teaching. Paper presented at the American Institute of Physics (AIP) conference, Penang, Malaysia.

Zaman, S. M. (1986). Place of man in the universe in the world-view of Islam. Islamic Studies 25(3), 325-331. 